\title{
Poetisk verbalbrug og sproglig datering af gammeltestamentlige tekster
}

\author{
Stud.theol. \\ Kasper Siegismund
}

\begin{abstract}
This article includes a short introduction to the general issue of linguistic dating of Old Testament texts as well as an appraisal of the alternative, non-chronological view of linguistic variation that has recently been put forward by Young, Rezetko and Ehrensvärd. Two poetical texts that are generally considered archaic (Exodus 15 and Judges 5), are examined using an approach to the verbal system in Biblical Hebrew poetry inspired by Alviero Niccacci. In this way it is demonstrated that supposedly archaic preterital use of yiqtol can be explained in other ways - which means that this feature is not a conclusive argument for early dating.
\end{abstract}

Key words: Biblical Hebrew - Exodus - Hebrew poetry - Judges - Linguistic dating - Old Testament.

At der er sproglig varians i det Gamle Testamente, er ikke i sig selv en kontroversiel betragtning. Det bliver det derimod, når det gælder det præcise omfang af forskellene, og især når det kommer til forklaringen på dem. Skyldes de kronologisk udvikling, sådan at de forskellige sprogformer afspejler forskellig affattelsestid, eller findes der andre forklaringer? Dette spørgsmål har i de seneste år været genstand for en omfattende diskussion blandt forskere, for valget af forklaringsmodel kan have vidtrækkende konsekvenser. Når man ser GT som et historisk dokument fra fortiden, der kan bruges som kilde, så bliver dateringen af afgørende betydning. ${ }^{1}$ Hvis en tekst som Sl 2 stammer fra kongetiden under et virkeligt israelitisk storrige, kan den være en forherligelse af undertrykkelse af andre folkeslag. Hvis den derimod er fra en senere diasporasammenhæng, kan den være et forfulgt mindretals utopi om en dag at få hævn over undertrykkerne. Når man fra

1. Jf. A. Hurvitz, "The Recent Debate on Late Biblical Hebrew: Solid Data, Experts' Opinions, and Inconclusive Arguments", Hebrew Studies 47 (2006), 191-210 (191): "Indeed, dating the biblical texts is indispensable for every aspect of research - textual, linguistic, literary, historical, theological - hence the persistent efforts invested over the years by Old Testament scholarship in dealing with chronological issues". 
"minimalistisk" side generelt har rykket GT’s affattelsestid længere og længere frem, har det fra anden side øget interessen for via sproget at vise, at en tidligere datering er korrekt. F.eks. skriver Rendsburg: "...the linguistic evidence $[. .$.$] contradicts the efforts to shift the date$ of clearly pre-exilic compositions to the post-exilic period". ${ }^{2}$

\section{Sproglig datering}

Avi Hurvitz har været en central skikkelse i bestræbelserne på at datere de gammeltestamentlige tekster med sproglige midler. Han ser en historisk udvikling fra EBH (Early Biblical Hebrew) til LBH (Late Biblical Hebrew) og forsøger at opstille en metode til at finde træk, der kan bruges som "independent chronological markers for dating purposes" (Hurvitz 2006, 205). Han understreger behovet for "solid, dependable criteria" (ibid., 191), og her er udgangspunktet tekster, der i den generelle konsensus ikke-sprogligt dateres sent, primært Est til Krøn, som ud fra indholdet klart kan dateres til efter eksilet. Her leder han efter neologismer, som bruges i stedet for andre udtryk med det samme indhold i andre tekster. Samtidig gør han opmærksom på en række faktorer, der kan gøre, at et træk ikke bør ses som sent, f.eks. aramæismer, der ikke ses som sene, hvis de optræder i poesi, dialektale tekster, hos udenlandske karakterer eller i visdomstekster.

De fundne træk skal så påvises i sene ikke-bibelske kilder (Qumran, rabbinsk litteratur) som et uafhængigt kontrolkorpus. De træk, man på denne måde har fastsat som sene, kan så bruges til at vise, at en hel tekst er sen, hvis den har en "heavy accumulation of neologisms" (ibid., 194). Denne metode skulle sikre, at der er tale om reel sproglig udvikling og ikke bare "stylistic variation devoid of chronological significance" (ibid.). Hurvitz understreger, at LBH både ses på det morfologiske og syntaktiske plan og i ordforrådet (ibid., 208), men det er primært leksikalske træk, han fokuserer på. Derimod ser Polzin syntaksen som det afgørende, ${ }^{3}$ ligesom også Joosten står for det synspunkt: "It would have been much harder for an ancient writer to distinguish earlier and later syntax than to do so for earlier and

2. G. A. Rendsburg, "Hurvitz Redux: On the Continued Scholarly Inattention to a Simple Principle of Hebrew Philology", Biblical Hebrew: Studies in Chronology and Typology, red. I. Young (London: T\&T Clark International 2003), 104-128 (107-8).

3. En sammenfatning af Polzins opfattelse findes i I. Young og R. Rezetko (with the assistance of M. Ehrensvärd), Linguistic Dating of Biblical Texts, vol. 1 (London: Equinox 2008), 25ff. I det følgende kaldet YRE, mens vol. 2 kaldes YRE2. 
later vocabulary". ${ }^{4}$ Denne fremhæven af syntaksen har givetvis en del for sig, men spørgsmålet fører over i kritikken af hele den kronologiske model, for ville det ikke være muligt for en dygtig sen forfatter at lave overbevisende efterligninger af et tidligere sprogtrin?

\section{Kritik af sproglig datering}

Young, Rezetko og Ehrensvärd udgav i 2008 en tobindsintroduktion til emnet sproglig datering, der samtidig også er et indlæg i debatten med et hovedsynspunkt, der kan sammenfattes således: "Thus, LBH is not simply postexilic Hebrew. It is one sort of $\mathrm{BH}$ in the postexilic period alongside $\mathrm{EBH}$. Both $\mathrm{EBH}$ and $\mathrm{LBH}$ use the same linguistic forms, just to different degrees, and the use of either EBH or LBH is a stylistic choice, not a consequence of chronology" (YRE2, 89). Et af deres grundlæggende argumenter mod den kronologiske opfattelse er forekomsten af EBH i sene tekster (YRE, 55-56). Hvis man kan vise, at indiskutabelt sene tekster kan skrives uden LBH-træk, så bliver det umuligt at påstå, at fravær af sådanne træk er et middel til tidlig datering. Young viser, at der er EBH i Qumran, ${ }^{5}$ og Ehrensvärd viser, at Hagg, Zak og Mal er EBH, og konkluderer, at "the exile did not put an end to the actual ability to produce this form of Hebrew". ${ }^{6}$ Modsat mener Hurvitz, at de tre skrifter har LBH-træk, selvom der ikke er mange, fordi de er fra begyndelsen af LBH-perioden (Hurvitz 2006, 206) - ifølge ham vil en sen forfatter altid afsløre, at han er sen. Derimod kan man indvende, at det er en ubeviselig påstand - “... but if he is consistent, detection is impossible"?

Et andet fundamentalt argument, man kan rette imod sproglig datering, er den cirkelslutning, der er udgangspunkt for det hele. Det er sproglige træk fra såkaldt indiskutabelt sene tekster, der bruges som holdepunkt, men derved har man på forhånd udskilt disse tekster

4. J. Joosten, "The Distinction between Classical and Late Biblical Hebrew as Reflected in Syntax", Hebrew Studies 46 (2005), 327-339 (329).

5. I. Young, "Late Biblical Hebrew and the Qumran Pesher Habakkuk", Journal of Hebrew Scriptures 8 (2008), article 25. Der er dog en del afvigende former i 1 QpHab og Qumran-tekster generelt (hvilket Young selv gør opmærksom på), men de tæller ikke med som LBH, fordi de ikke stemmer med de LBH-træk, der er opstillet på baggrund af de bibelske LBH-tekster. Hvis Qumran-teksterne som udgangspunkt var med i det tekstkorpus, der danner grundlag for definitionen af LBH, så ville resultatet blive anderledes.

6. M. Ehrensvärd, "Linguistic Dating of Biblical Texts", Biblical Hebrew: Studies in Chronology and Typology, red. I. Young (London: T\&T Clark International 2003), 164-188 (186).

7. D.A. Robertson, Linguistic Evidence in Dating Early Hebrew Poetry (Missoula, Montana: Society of Biblical Literature 1972), 2. 
som sarligt sene $i$ modsatning til resten, der så må være tidligere, hvilket er det, man gerne skulle bevise. Antallet af træk, der skal til, før en tekst kaldes LBH, er heller ikke fast, men "dependent on the subjective judgment of the individual scholar" (YRE, 94).

Forekomsten af forskellige dialekter/sociolekter (geografisk hhv. socialt bestemte varianter) i $\mathrm{BH}$ er også et potentielt underminerende argument for den sproglige datering, og det samme gælder tekstkritikken. Én ting er at datere sproglige træk, noget andet er teksterne, der indeholder disse træk. Hvis sproget skal bruges til datering af selve teksten, forudsætter det, at den overleverede sprogform er identisk med den oprindelige forfatters. Young mener, at dette ikke kan være tilfældet, men at det (modsat Hurvitz' opfattelse, citeret YRE, 17) er sandsynligt, at "all features of the biblical text were subject to extensive editorial revision during the Second Temple period". ${ }^{8} \mathrm{LBH}$-træk kan snige sig ind senere, eller omvendt kan et LBH-træk senere "rettes" til EBH, uden at det behøver betyde en total gennemredigering af teksterne (så ville der jo ikke være nogen varians). Spørgsmålet om teksternes enhed eller sammensætning af oprindeligt adskilte dele er også centralt, f.eks. kan et stykke af en tekst pludselig opvise en afvigende sprogform: Ez 37 og 2 Kong 23 har eksempelvis en hel række af weqatal-former om fortidige hændelser.

Derfor kan omfattende statistiske undersøgelser være værdifulde, og det er, hvad YRE har foretaget for forekomsten af LBH-træk i udvalgte tekststykker (YRE, 131-136). De skriver selv, at udvalget er "somewhat random" (ibid., 131), og i betragtning af teksternes mulige sammensatte karakter gør det undersøgelsen mindre brugbar. Ideelt set skulle optællingen dække hele GT. En anden væsentlig indvending mod deres metode er, at hvert træk kun tælles med én gang: "Once an author has demonstrated the possibility of using a particular LBH feature, there is no reason it cannot be repeated as many times as opportunity presents itself" (ibid., 130). I betragtning af det tekstkritiske spørgsmål må denne tilgang ses som fejlagtig. Det er væsentligt at vide, om et træk optræder én gang (så er sandsynligheden for, at det er en smutter fra en afskrivers side, måske større) eller om det er konsekvent gennemført. I praksis går de faktisk i nogle tilfælde imod deres princip og tæller alle forekomster af et træk, i og med at nogle af trækkene er af typen "preference for X" (f.eks. en tendens til at bruge yna]frem for $y\left(\mathrm{k}^{\mathrm{\theta}}\right)$. Desuden tager denne optællingsmetode ikke alvorligt, at sprog typisk udvikler sig på en måde, der skematisk kan fremstilles, så det ligner et fladtrykt $s$ på en kurve: En innovation

8. I. Young, "Late Biblical Hebrew and Hebrew Inscriptions", Biblical Hebrew: Studies in Chronology and Typology, red. I. Young (London: T\&T Clark International 2003), 276-311 (310). 
starter langsomt i nogle få ord eller blandt få personer, hvorefter der sker en "eksplosion" i udbredelsen over kort tid, og så følger en evt. langvarig periode, hvor der stadig er få områder af sproget, der ikke er påvirkede. ' Dvs. forekomst af nogle få LBH-træk i en EBH-tekst er ikke i sig selv problematisk for den kronologiske tilgang. På trods af denne optællingsmetode, som potentielt skubber argumentet i YRE's favør, viser optællingen overordnet set en klar tendens til, at de traditionelt set sene tekster har flest LBH-træk. Dette er selvfølgelig også, hvad man ville vente, da LBH-trækkene netop er opstillet ud fra disse tekster. Kort sagt demonstrerer optællingen bare, at der er en varians i BH, men den viser også, at selv de mest EBH-agtige tekster også har LBH-træk. Hertil kommer Youngs påvisning af, at der også er LBHtræk i føreksilske inskriptioner. ${ }^{10}$

\section{"Arkaisk" poesi}

Tidlig datering er for fortalere for sproglig datering så at sige "default" - hvis der ikke er nogen LBH-træk, må det være gammelt. ${ }^{11}$ Som kritikerne har vist, er dette ikke nødvendigvis en holdbar slutning. Derfor kunne det være tillokkende at lede efter træk, der i sig selv kunne vise, at en tekst er gammel. Det er da også en udbredt opfattelse, at der findes tekster i GT, som sprogligt er udpræget gamle, navnlig visse poetiske indslag i Mosebøgerne (1 Mos 49, 2 Mos 15, 4 Mos 23-24, 5 Mos 32-33) og Dom 5, samt 2 Sam 22/Sl 18 og Hab 3. Især Dom 5 anses typisk for at være meget gammel, langt ældre end den forudgående prosaberetning. ${ }^{12}$ Spørgsmålet er, om der er sproglige grunde til at antage en særlig høj alder for disse tekster.

9. Dette problem påpeges i flere af bidragene i Diachrony in Biblical Hebrew, red. C.L. Miller-Naudé og Z. Zevit (Winona Lake, Indiana: Eisenbrauns 2012), hvor en række forskere forsøger at imødegå YRE's udfordringer ved at fokusere mere på generel lingvistisk teori og erfaringer fra andre sprogs historie. Pointen med "s-kurven" blev allerede taget op i forbindelse med BH af J.A. Naudé, "The Transitions of Biblical Hebrew in the Perspective of Language Change and Diffusion", Biblical Hebrew: Studies in Chronology and Typology, red. I. Young (London: T\&T Clark International 2003), 189-214 (200).

10. I. Young, "Late Biblical Hebrew and Hebrew Inscriptions", Biblical Hebrew: Studies in Chronology and Typology, red. I. Young (London: T\&T Clark International 2003), 276-311.

11. Direkte udtrykt hos Rendsburg (2003), 111: “... the default is to assume a pre-exilic date".

12. C. Levin, "Das Alter des Deboralieds", Fortschreibungen (Berlin: Walter de Gruyter 2003), 124-141 (124): "Bis heute wird das Deboralied fast unangefochten - mit Wellhausens Worten - als 'das früheste Denkmal der hebräischen Literatur' angesehen". 
Et hovedargument for tidlig datering er forekomsten af yiqtol-former med fortidsbetydning, ${ }^{13}$ altså relikter af en oprindelig præteritumsform, som ellers i hebraisk kun er bevaret med wa- foran. Lad det her være nok at antyde, at man kan rekonstruere en ursemitisk præteritumsform *yáqtul over for en jussiv *yaqtúl, desuden en præsens *yaqattal, som er gået tabt i vestsemitisk, hvor man til gengæld har udviklet en "imperfektum" *yaqtulu, der svarer til præteritum (eller jussiv) med konjunktivsuffiks i akkadisk. ${ }^{14}$ Desuden fandtes en stativ *qatal(a), der oprindelig er en nominalform primært med tilstandsbetydning som i akkadisk (betegnelsen stativ er egentlig uheldig, da det skaber forvirring ift. verbaltypen stativ som modsætning til fientisk, hvorfor den ældre betegnelse permansiv måske i virkeligheden ville være at foretrække). Denne form udviklede sig i både vest- og sydsemitisk til en egentlig finit verbalform, "perfektum". ${ }^{15}$

I nærværende sammenhæng er spørgsmålet, om det er nødvendigt at tolke de formodede præteritumsformer fortidigt, sådan som f.eks. David A. Robertson gør i sin omfattende gennemgang af materialet fra 1972 (se note 7 ovenfor). Han gennemgår her en lang række poetiske tekster og sammenligner dem på den ene side med standarden i tekster, der på ikke-sprogligt grundlag dateres sent, og på den anden side med tidligt poetisk hebraisk. Sidstnævnte er en sprogform, som han har rekonstrueret ud fra træk i ugaritisk og Amarna-kanaanæisk, sammenholdt med sjældent forekommende syntaktiske og morfologiske træk i bibelsk poesi. Han gør selv opmærksom på det hypotetiske i tilgangen og peger på muligheden for at forklare sjældne former på anden vis end ved høj alder og på muligheden for bevidst arkaisering (Robertson 1972, 4-5). Hvis det skal kunne bruges som argument for tidlig datering, skal der være tale om et tydeligt mønster, altså en høj forekomst af tidlige træk og få eller ingen senere former (ibid., 28, 41 og flere andre steder). Når han behandler verbalsyntaksen med fokus på brugen af yiqtol som præteritumsform, er hans princip, at "only passages which beyond reasonable doubt refer to past time are eligible for consideration" (ibid., 9), og det er her, svagheden ved hele metoden ligger. Han tager nemlig en meget stor del af formerne som fortidsformer og forklarer kun en lille del som frekventativer, mens han i mange tilfælde overvejer det, men afviser. En alternativ tilgang til læsningen af poesi, som Alviero Niccacci for nylig har fremført, vil

13. Her bruges de rent deskriptive betegneler yiqtol (traditionelt "imperfektum"), qatal ("perfektum"), wayyiqtol ("konsekutiv imperfektum"), weqatal ("konsekutiv perfektum”).

14. I hebraisk er *yáqtul, *yaqtúl og *yaqtulu i de fleste tilfælde faldet sammen.

15. En god generel indføring kan findes hos E. Lipiński, Semitic Languages. Outline of a Comparative Grammar (Leuven: Peeters 1997). 
imidlertid sætte store spørgsmålstegn ved Robertsons konklusion om, at 2 Mos 15 må være en meget tidlig tekst. ${ }^{16}$

\section{Poetisk verbalbrug}

"BHP [Biblical Hebrew Poetry] remains a mystery from the point of view of the verbal system used while prose shows a substantial coherence. The most remarkable area of disagreement is an apparently free alternation of Qatal, Yiqtol and Weqatal forms in poetry". ${ }^{17}$ Sådan skrev Alviero Niccacci i 1997 og gav dermed udtryk for en opfattelse, som er enormt udbredt. I en af de nyere danske begyndergrammatikker gengives den f.eks. således: "I salmer og anden poesi kan perfektum og imperfektum dog bruges i flæng, tilsyneladende uden betydningsforskel". 18

I artikler fra 2006 og 2010 slår Niccacci imidlertid til lyd for en ny opfattelse. ${ }^{19}$ Her ses det poetiske verbalsystem som "basically the same as in prose, more precisely in direct speech" (Niccacci 2010, 114). Forskellen er, at poesi ikke er en fortløbende fortælling, men segmentalt opbygget af mindre enheder med parallelisme, hvorfor der lettere kan skiftes mellem forskellige tidslige sammenhænge. Denne segmentale, abrupte karakter ses også i den begrænsede brug af almindelige syntaktiske markører som bestemt artikel, objektsmar$\mathrm{k} ø \mathrm{r}$ og relativpronomen. I en lineær, fortællende prosatekst forventes det normalt, at man holder sig til en logisk tidsfølge, men i et digt eller en sang kan man let skifte mellem aktører, tidsplaner osv., uden at det betyder, at grammatikken er grundlæggende anderledes. Ifølge Niccacci, skal man altså "respect the verbal forms for what they are and try to interpret them accordingly, even when one finds abrupt transitions..." (ibid., 117).

16. Robertson inddrager også andre sproglige træk end verbalbrugen, men de er også åbne for kritik. F.eks. 3.pl.-suffiks -mw, der behandles i Y. Bloch, "The ThirdPerson Masculine Plural Suffixed Pronoun - $m w$ and Its Implications for the Dating of Biblical Hebrew Poetry", Diachrony in Biblical Hebrew, red. C.L. Miller-Naudé og Z. Zevit (Winona Lake, Indiana: Eisenbrauns 2012), 147-170.

17. A. Niccacci, "Analysing Biblical Hebrew Poetry", Journal for the Study of the Old Testament 74 (1997), 77-93 (91).

18. F.A.J. Nielsen, Bibelsk Hebraisk Grammatik - en indforing. I samarbejde med M. Ehrensvärd (København: Forlaget Anis 2008), 120, \$3.3.2.4.2.

19. A. Niccacci, "The Biblical Hebrew Verbal System in Poetry", Biblical Hebrew in Its Northwest Semitic Setting: Typological and Historical Perspectives, red. S.E. Fassberg og A. Hurvitz (Winona Lake, Indiana: Eisenbrauns 2006), 247-268. A. Niccacci, "An Integrated Verb System for Biblical Hebrew Prose and Poetry", Congress Volume Ljubljana 2007, red. A. Lemaire (Leiden: Brill 2010), 99-127. 
En læsning af den gammeltestamentlige poesi ud fra en grundlæggende opfattelse af teksterne som segmentale kan få store konsekvenser for forståelsen generelt. I stedet for at tage udgangspunkt $i$, at konteksten for hele teksten nok er fortidig og så oversætte som én lang historisk beretning om noget, der er sket i fortiden, vil man få en vekslen mellem fortællende afsnit med fortidige verbalformer og afsnit med f.eks. håb om fremtiden, bøn eller anråbelse af Gud, hvor man kan have verber med futurisk eller jussivisk betydning. Indvendingen mod denne tilgang er, at der også inden for de enkelte segmenter, som man meningsfuldt kan opdele en tekst $i$, findes qatal og yiqtol, der optræder parallelt, tilsyneladende i flæng, men det opregner Niccacci en række forklaringer på (ibid., 115-17): Det kan være reelt tidsskifte, der bl.a. kan være udtryk for det, han kalder "bønnens dynamik" - en vekslen mellem udtryk for tillid til Guds tidligere handlinger, den nuværende situation og håb for fremtiden. En særlig type af denne vekslen kalder Niccacci "merismus", hvilket vil sige, at man udtrykker en totalitet ved at nævne yderpunkterne: han har gjort - han vil gøre, dvs. han gør altid. En uventet yigtol kan også skyldes, at verbet optræder i en betingelsessætning uden konjunktion eller eventuelt med en konjunktion, der underforstås fra en foregående sætning. Endelig kan det hyppigt dreje sig om frekventativ, habituel, deskriptiv baggrundsinformation - altså et spørgsmål om aspekt, hvilket også er den måde yiqtol-former typisk bruges på i fortidig kontekst i prosa (f.eks. 1 Mos 29,2; 4 Mos 9,18;1 Sam 1,7).

\section{Stativ/fientisk}

Endnu en forklaring, som må ses som ret væsentlig, nævner Niccacci kun i en fodnote (Niccacci 2010, 118, note 40) uden at komme nærmere ind på dens relevans. Det drejer sig om verbernes basale betydningstype - om de er stative eller fientiske. ${ }^{20}$ Fientiske verber betegner en hændelse, der finder sted, mens stative betegner en tilstand - i oversættelse typisk udtrykt vha. "at være" plus et adjektiv, men gruppen inkluderer også sindstilstandsverber og verber som dm[ og bvy. I disse verber har qatal typisk præsensbetydning. Dette kan skyldes, at man har haft en fientisk betydning i tankerne, f.eks. med grundbetydningen "stille sig", dvs. qatal "han har stillet sig", hvilket er det

20. Jf. P. Joüon og T. Muraoka, A Grammar of Biblical Hebrew (Rom: Editrice Pontificio Instituto Biblico 1991), 357. De skelner mellem "stative" og "active", hvilket er uheldigt, da aktiv jo også er del af modsætningen passiv/aktiv. B.K. Waltke og M. O'Connor, An Introduction to Biblical Hebrew Syntax (Winona Lake, Indiana: Eisenbrauns 1990), 481 kalder det "stative" og "fientive". 
samme som "altså står han nu". Stativverber i qatal kan imidlertid også have fortidsbetydning. ${ }^{21}$ Det er væsentligt, at der ikke er tale om nogen fast skelnen - stativverber kan også bruges fientisk, dvs. det samme verbum kan både betyde "være tung" og "blive tung" eller "stå" og "stille sig". Ligeledes kan et fientisk verbum bruges i qatal i egentlig perfektivisk (førnutidig) betydning, hvor det aktuelle resultat af en fortidig hændelse er i fokus. I den aktuelle problemstilling mht. poetisk verbalsyntaks er pointen, at et stativverbum i qatal (med præsensbetydning) sagtens kan stå parallelt til et fientisk verbum i yiqtol (som altså også har en præsentisk/generel betydning), uden at der ligger en tidsmæssig forskel i det. Et eksempel er S1 2,1: W gp " kan oversættes med "være urolig", altså et stativverbum, der derfor står i qatal, uden at det giver en fortidsbetydning, mens Vhen y< er fientivt og derfor bruger yiqtol til at udtrykke det samme, som stativverbet gør i qatal.

Rent bortset fra den generelle betydning, som Niccaccis tilgang vil have for forstålsen og oversættelsen af hebraisk poesi, kan denne måde at læse teksterne på finde anvendelse, når det gælder spørgsmålet om sproglig datering af de gammeltestamentlige tekster.

Jeg har gennemgået de ovennævnte tekststykker for at se om den formodet arkaiske verbalsyntaks kan forklares vha. den segmentale opfattelse af poesien og de forskellige forklaringer på skift i verbalformerne. Først har jeg inddelt teksterne i mindre segmenter med samme type verbalformer. At der skiftes til en anden verbalform og en anden tid i et følgende segment, er, hvad vi må forvente på baggrund af poesiens segmentale karakter - f.eks. har vi i 2 Mos 15 et fortidigt fortællende segment i v. 4-5, fulgt af en lovprisning i v. 6-7 med yiqtol-former til udtryk for samtidighed, igen efterfulgt af et fortællende segment i v. 8-10 med fortidsformer, med indlagt direkte tale i v. 9 med yiqtol'er. Det, der er det centrale, er imidlertid, når der er afvigelser inden for sådanne segmenter - de skal forklares. Generelt bemærkes det, at relativsætninger, årsagssætninger osv. falder uden for den overordnede struktur. Der er f.eks. ikke noget påfaldende $\mathrm{i}$ at have en qatal i en relativsætning, der forklarer baggrunden for noget $i$ en præsentisk hovedsætning. Her gengives eksempler på alternative forklaringer af yiqtol-former i 2 Mos 15 og Dom 5, men samme principielle resultat nås i de andre stykker.

21. Joüon/Muraoka (1991), 360: "Like the qatal of active [dvs. fientive] verbs (and perhaps on their analogy) the qatal of stative verbs can also be used for the past". 


\section{Mos 15,1-18}

I v. 4-5 er vi i en fortidig, fortællende sammenhæng, hvor yiqtol'en Imyb $k$ y (v. 5) falder udenfor. I stedet for at oversætte den som en punktuel hændelse i fortiden, kan man enten tage den som deskriptiv baggrundsinformation - "de druknede i Sivhavet, idet dybet dækkede dem”, eller måske er det mere nærliggende at tage det helt bogstaveligt: "De druknede i Sivhavet, dybet dækker dem [den dag i dag, for de ligger der stadig]". En lignende udtryksmåde findes for øvrigt i Es 43,17b, hvor DO oversætter "De lå der og kunne ikke rejse sig, de slukkedes, gik ud som et lys". Her lægger yiqtol-formerne måske også op til en præsentisk oversættelse, og qatal'erne kan så oversættes førnutidigt: "De ligger [der stadig] og vil ikke rejse sig, de er blevet slukket osv."

I v. 12-15 har vi igen et fortællende, fortidigt segment. Der er tre yiqtol'er (v. 12, 14, 15), der skal forklares: Am[ ebJi (v. 12). Denne yigtol, som vel har jussiv betydning, kan tolkes som en slags direkte tale: "Du strakte din højre ud [som befaling]: 'Lad jorden opsluge dem”'. Eller det kan tolkes som det følgende ! !tG' † (v. 14), hvor der er tale om deskriptiv baggrundsinformation, "idet/mens de rystede". I v. 15 har vi så Amzł a yo som også kunne ses som deskriptiv baggrundsinformation, men det giver måske dårligere mening med et verbum, der betyder "gribe". Ellers kan man inddrage hele sætningen fra za 'til $\mathrm{d}$ [ r", så en sætningsindleder bestemmer flere verbers form. za' kan følges af både qatal og yiqtol, og man kunne så påstå, at yiqtol'en egentlig er det forventede (jf. v. 1 h v mor w i i" za '), så det altså er qatal'en ( Wh h hn), der skal forklares. Her kunne man så påberåbe sig et "metri causa”, idet yiqtol ville have en stavelse mere. Dette er selvfølgelig en ret usikker tilflugt, da vores viden om hebraisk metrik er temmelig begrænset. Her er pointen blot, at hvis valget af verbalform tilføjer eller fjerner en stavelse, så vil det påvirke metrum, ligegyldigt hvordan dette nærmere er indrettet. ${ }^{22}$ At man af metriske hensyn bruger en kortere form, ændrer ikke nødvendigvis noget ved den grundlæggende grammatik (ligesom man heller ikke kan drage vidtgående konklusioner om moderne dansk syntaks ud fra ordstillingen i en sølvbryllupssang). Hvis man vælger denne forklaring, må man sige, at den følgende qatal er en ny sætning, der ikke er underlagt za!.

22. Jf. Joüon/Muraoka (1991), 353, der taler om “metrical necessity" mht. verbalbrug i poesi. 


\section{Dom 5,2-31}

I v. 6-7 har vi en fortællende, fortidig kontekst med qatal'er og én yiqtol: Vk $\mid$ yE (v. 6). Den må ses som udtryk for durativt aspekt i fortiden. Qatal'en W d $\aleph^{\prime}$ udtrykker det samme, hvis det tages i betydningen "ligge øde hen", altså stativ, her i fortid.

I v. 8 optræder to yiqtol'er: r xpyl og har 炈(v. 8). "This entire verse is notoriously difficult to translate". ${ }^{23} \mathrm{DO}$ oversætter fortidigt og i pluralis: "De valgte nye guder, de ikke før havde kendt", ${ }^{24}$ men mere oplagt er det måske at læse noget i stil med "lad ham vælge nye guder" eller måske "lad Gud vælge nye, så [vil der være] kamp i portene, ${ }^{25}$ hvis (eller mon?) der ses skjold og spyd blandt Israels 40.000". En indvending mod den læsning ville være, at Gud ellers kaldes Jahve i digtet, mens yhl a/kun bruges i formen I a ef yl yh ea/som apposition til Jahve. Pointen er under alle omstændigheder, at man ikke behøver at oversætte fortidigt.

I v. 13-18 har vi en beskrivelse af de forskellige stammer. Der er både nominalsætninger, qatal'er og yiqtol'er, der veksler. r Vyy"og! !K v yl (v. 17) står hver især parallel til qatal. Dette er et godt eksempel på stativ/ fientisk-forklaringen. Vi har tre forskellige verber, der alle sammen kan være både stative og fientiske og derfor kan bruges i både yiqtol og qatal på samme tidsplan.

I v. 25-30 er vi igen i en fortællende sammenhæng om drabet på Sisera og om Siseras mor. Der er tre yiqtol'er. Ved hnl l p Ti (v. 26) kan man måske påberåbe sig den deskriptive baggrund igen (samtidighed), eller man kan sige, at det er en slags dramatisk præsens - det er her, skiftet sker fra ro til angreb, "the cathartic moment of release for the audience". ${ }^{26}$ Man kunne evt. anføre en lydlig tilskyndelse til at vælge en yiqtol her, idet man med t-præfikset opnår en hel række

23. R. G. Boling, Judges, (Garden City, New York: Doubleday \& Company, Inc. 1975), 109. I det hele taget er der ret mange problematiske steder i Dom 5, jf. også LXX, der i én version simpelthen transkriberer hebraiske ord i v. 16 og 22.

24. Denne oversættelse forudsætter $h$ i stedet for $X \mathrm{i} \sim X \mid$ ', omvokalisering af $\sim$ yr [ $\mathrm{V}$. samt indsættelse af et "ikke", ud over ændringen til pluralis.

25. $\left.\sim X\right|^{\prime}$ med den vokalisering oversættes til krig eller kamp, men det optræder ikke andre steder. Alternativt læses det som "brød”, og hvis man ændrer prikken over X i det følgende ord, kan man få LXX’s bygbrød. Man kunne i den anledning henvise til et følgende kapitel i Dom, hvor nogle soldater drømmer om Gideon i form af et bygbrød, der knuser deres lejr $(7,13)$. Så kunne man oversætte det følgende a l i 5,8 som emfatisk nægtelse, og meningen skulle så være, at Gud vil vælge nye ledere som Gideon, så der slet ikke er brug for skjold og spyd.

26. A. J. Hauser, "Two Songs of Victory: A Comparison of Exodus 15 and Judges 5", Directions in Biblical Hebrew Poetry, red. E.R. Follis (Sheffield: JSOT Press 1987), 265-284 (276). 
af dentale lyde efter hinanden, som man ikke ville få med en qatal (yāDāh layyāTeD Ti...). Ved h MnkKT; og byw T' (v. 29) kunne man måske også tale om et dramatisk skifte, der skal understrege det tragiske i billedet af moren, der prøver at bilde sig selv noget ind. ${ }^{27}$ At begge verber er yiqtol og optræder i et klart afgrænset segment (med direkte tale til begge sider), gør denne forklaring mere plausibel - så længe der er tale om forskellige poetiske undersegmenter, er det ikke uventet med spring mellem tidsformerne.

\section{Hvad er der blevet vist?}

En tilsvarende læsning kan foretages af andre poetiske stykker, og overalt kan man give alternative forklaringer på brugen af yiqtol. Her er det væsentligt at understrege, at der ikke kan blive tale om egentlige beviser. At vi kan "bortforklare" de fleste eller alle af de påståede arkaismer inden for verbalsystemet og tolke dem på en anden måde, beror måske først og fremmest på, at poesi af natur er mangetydig, og derfor er det måske ikke så underligt, at det er muligt at bruge Niccaccis metode. Det væsentlige i dateringssammenhæng er ikke så meget egentlige beviser, men påvisning af muligheden for en anden tolkning og dermed underminering af et argument for sproglig datering.

Et centralt problem er, at vokaler og accenter som bekendt først er sent tilføjet til konsonantteksten ud fra forskellige traditioner. Det betyder, at en eventuel oprindelig skelnen mellem en fortidig *yíqtol over for en jussiv eller imperfektivisk *yiqtól(u) ikke kan ses, mens der sagtens kan have været en tydelig, hørbar forskel, da konsonantteksten blev nedskrevet. Man kunne i denne sammenhæng inddrage de tidligste versioner som argument. I LXX oversættes generelt fortidigt (se dog 2 Mos 15,16-18), men hvilken betydning skal man tillægge dette? Peger det på, at oversætterne har haft en læsetradition, der klart markerede præteritum (f.eks. ved trykplacering), eller tyder det på en mere fortolkende tilgang, hvor oversætterne (som en moderne oversætter) ud fra sammenhængen har prøvet at forstå meningen med en overleveret tekst? Som Barr siger “... many passages which are difficult for us today were difficult for the ancient translators also". 28

Der er andre træk end verbalbrugen, som kan fremføres som særligt arkaiske i de behandlede tekster, men i alle tilfælde er det også her muligt at give en eller flere alternative forklaringer - typisk aramæ-

27. Hauser (1987), 276: "However, any potential feelings of sympathy are quickly removed in vv. 29-30, where the scene reaches its climax".

28. J. Barr, Comparative Philology and the Text of the Old Testament, (Winona Lake, Indiana: Eisenbrauns 1987), 266. 
isk indflydelse eller analogisk gendannelse internt $\mathrm{i}$ hebraisk (f.eks. kunne en oprindelig endelse på -ti i 2.sg.f., som normalt er blevet til -t, gendannes i analogi med former med objektssuffiks, hvor i'et regulært var bevaret). Det viser sig således, at mange af de "gamle" træk ved verbalbrugen ikke behøver at være gamle, og ligeledes er det muligt at tilbyde alternative forklaringer på mange andre foreslåede "arkaiske" træk, ligesom nogle træk også kan tolkes som sene (Levin 2003, 125-6). Der er derfor al mulig grund til at se eventuelle træk, som ikke har kunnet elimineres vha. Niccaccis metode eller andre forklaringer, som arkaisering - altså ikke udtryk for, at selve teksterne nødvendigvis er gamle, men som forsøg på at give dem et skær af xlde.

\section{Alternative forklaringer på sproglig varians}

For afslutningsvis at vende tilbage til den generelle kritik af sproglig datering kan man rejse spørgsmålet om, hvad den varians, vi kan iagttage, er udtryk for, hvis det ikke er kronologi. Der er varians i alle sprog på ethvert trin i deres udvikling, så der findes flere synkrone forklaringsmodeller, f.eks. genre, dialekt, sociolekt, diglossi (talesprog vs. formelt, litterært sprog, hvor "LBH-træk" så kan forklares som talesprogsafsmitning på det formelle sprog). Problemet med alle disse forklaringer er imidlertid det samme som med den kronologiske model. De tekstkritiske og litterære forbehold er de samme, og det gælder også her, at vi ikke har noget kontrolkorpus: Vi har f.eks. ikke nogen omfattende tekstsamling af $100 \%$ sikre tekster fra et bestemt dialektområde, der er sammenlignelige med GT, eller noget, vi med sikkerhed kan sige, tilhører en bestemt social gruppe over for en anden. YRE's forklaring er "stil". De understreger flere gange, at der er tale om samtidigt eksisterende varianter, som forfatterne vælger ud fra. De gør meget for at underminere enhver kronologisk forklaring ved flere gange at understrege, at mange LBH-træk er "typologically earlier" end de tilsvarende EBH-træk (især YRE, 76, 119, YRE2, 155). Imidlertid viser det sig, at alle deres eksempler kan forklares på langt mere nærliggende vis. Sprog udvikler sig ikke i én lige linje, men der kan ske analogiske omdannelser, hyperkorrektion osv., som genskaber noget, der ligner et tidligere sprogtrin. ${ }^{29}$ Inden man afskriver kronologien helt, må det også understreges, at al synkron varians har en diakron baggrund, hvis man ikke vil forfalde til sproglig kreationisme med uforanderlige dialekter skabt efter deres arter én gang

29. Dette nævner de også selv (YRE2, 156), men affærdiger det. 
for alle. "Stilvalg" er i sig selv egentlig mere et andet ord for variansen end en forklaring på den. YRE kalder de to stilarter "conservative and non-conservative" og understreger, at konservativ skal forstås som "moderate, cautious, avoiding extremes', rather than conservatism in the sense of favouring an older style" (YRE2, 96). De foreslår, at stilvalget kan være ideologisk eller intellektuelt betinget, hvorved det afgørende bliver tekstens forudsatte publikum eller formål (ibid., 99). Der er på den måde noget ubestemt over brugen af ordet "stil", hvilket også er blevet påpeget fra flere sider. ${ }^{30}$

Spørgsmålet er desuden, om ikke de tekstkritiske indvendinger og teksternes evt. sammensatte karakter også underminerer værdien af denne forklaring - hvordan kan man tale om forfatterens personlige stilvalg, når vi ikke har forfatterens oprindelige tekst?

Frank Polak har pointeret, at "the imitation hypothesis must assume a considerable corpus serving as prototype", ${ }^{31}$ hvorved han hentyder til idéen om, at senere forfattere efterligner tidligere skrifter. Hvis en bestemt sprogform skal blive lærd sprog eller være ideologisk/ religiøst forbillede, forudsætter det så ikke, at de sene forfattere har en eller anden mere eller mindre "kanonisk" tradition at holde sig til, enten i form af mundtlig overlevering eller ikke-bevarede skrifter, eller fordi nogle af de tekster, vi har, faktisk er gamle? ${ }^{32}$ YRE anerkender (i modsætning til deres øvrige argumentation mod kronologiske forklaringer) selv dette, når de siger, at sene forfattere kunne skrive $\mathrm{EBH}$, fordi de var blevet trænet "by mastery of earlier, classical texts in EBH” (YRE, 275-6).

Når der allerede i tidlige inskriptioner optræder træk, som ellers først bliver almindelige i mishnaisk hebraisk (ibid., 242-3), tyder det

30. R.D. Holmstedt, "Historical Linguistics and Biblical Hebrew", Diachrony in Biblical Hebrew, red. C.L. Miller-Naudé og Z. Zevit (Winona Lake, Indiana: Eisenbrauns 2012), 97-124 (113) peger på, at en diskussion om "stil" forudsætter, at man først beskriver den norm, som den stilistiske variation er afvigelser fra. B.E. Dresher, "Methodological Issues in the Dating of Linguistic Forms", Diachrony in Biblical Hebrew, red. C.L. Miller-Naudé og Z. Zevit (Winona Lake, Indiana: Eisenbrauns 2012), 19-38 (34-35) kritiserer stilvalgsteorien for at være uden "testable empirical consequences", fordi valgene dybest set er uforudsigelige.

31. F. H. Polak, "Style is More than the Person: Sociolinguistics, Literary Culture and the Distinction between Written and Oral Narrative", Biblical Hebrew: Studies in Chronology and Typology, red. I. Young (London: T\&T Clark International 2003), 38-103 (100).

32. Man kan sammenligne med følgende citat om avestisk fra P.O. Skjærvø, "Old Iranian", The Iranian Languages, red. G. Windfuhr (London: Routledge 2009), 43-195 (44): "Note also that the suggestion that Old Avestan might in fact be later than Young Avestan, adducing the comparison with the use of Latin in Europe long after it was no longer a spoken language, is faulty, as Latin was learned from existing manuscripts and grammars". 
så på, at $\mathrm{BH}$ generelt er en arkaiserende, lærd sprogform med gamle traditioner bag, som søger at undgå for mange nydannelser? Måske ligger der bag et evt. "konservativt stilvalg" alligevel noget kronologisk i form af en ældre tradition - det er bare i de enkelte tilfælde umuligt at bevise, om det er reelt gammelt eller noget, der giver sig ud for at være det, når vi ikke har andre, ydre argumenter.

\section{Konklusion}

En gennemgang af den formodet "arkaiske" poesi bekræfter, at den kritiske tilgang til brug af sproglige argumenter til datering har meget for sig. Det centrale at holde fast i er YRE's fundamentale pointe, at vi ikke vha. sproget kan levere egentlige beviser for teksternes alder. Samtidig må man sige, at det heller ikke er bevist, at kronologien ikke spiller en rolle, og man kan sætte spørgsmålstegn ved, hvor overbevisende de alternative forklaringer på variansen er. Så længe man tager de tekst- og litterærkritiske og andre indvendinger alvorligt, er der ingen grund til at afskrive kronologiske forklaringer fuldstændigt. Hvis der er noget, der står fast mht. alle sprog, så er det, at de udvikler sig over tid. Generelt gælder det, at ingen én-strenget model kan forklare variansen ordentligt - man må inddrage hele samspillet af forskellige faktorer, både de synkrone og de diakrone. ${ }^{33}$ Først og fremmest må man være klar over, at forklaring ikke er det samme som forudsigelse. Fordi man i et specifikt tilfælde mener at kunne forklare en teksts særtræk, betyder det ikke, at man kan sige, at sådanne træk altid peger på den samme baggrund. Man kunne i denne sammenhæng pege på, at fremtidigt arbejde med den sproglige varians i GT bør have et udgangspunkt, der ikke på forhånd opdeler GT i tidligt og sent - og dermed forudsætter det, man gerne vil bevise. De sene træk må opstilles på basis af materiale uden for GT, som vi med sikkerhed ved, er sent, og derudfra må man undersøge GT, ikke for at finde endegyldige beviser for en datering, men som del af en alsidig bedømmelse af teksternes historiske baggrund og kronologiske placering. Man må til stadighed tage de litterære, genremæssige, tekstkritiske osv. forbehold med $\mathrm{i}$ betragtning, $\mathrm{i}$ bevidsthed om den flertydighed og de forskellige tolkningsmuligheder, som forskellige dateringsmuligheder giver.

33. Jf. Holmstedt (2012), 117: "Why must it be either-or? It does not necessarily follow that one or two cases in which a borrowed word is used for style undermines its diachronic explanation". 